\title{
Using the Portfolio Method as a Tool for Evaluating Educational Achievements in the Conditions of Professional Training
}

\author{
Ekaterina Zinovyeva \\ Economy and Management Department \\ Nosov Magnitogorsk State Technical University \\ Magnitogorsk city, Russian Federation \\ ekaterina_7707@mail.ru \\ Liliia Votchel \\ Economy and Management Department \\ Nosov Magnitogorsk State Technical University \\ Magnitogorsk city, Russian Federation \\ votchellm@mail.ru
}

\author{
Valeriya Vikulina \\ Economy and Management Department \\ Nosov Magnitogorsk State Technical University \\ Magnitogorsk city, Russian Federation \\ vvvlerkin@mail.ru \\ Yuliya Laktionova \\ Institute of Energy and Automated Systems \\ Nosov Magnitogorsk State Technical University \\ Magnitogorsk city, Russian Federation \\ uli_laktionova@mail.ru
}

\author{
Irina Belousova \\ Institute of Energy and Automated Systems \\ Nosov Magnitogorsk State Technical University \\ Magnitogorsk city, Russian Federation \\ bid711@mail.ru
}

\begin{abstract}
The value of the portfolio method lies in the fact that such an educational process can be built around it and in connection with it that allows you to develop or form some cognitive-personal qualities (competencies) that are put forward by the world of education and work as necessary for each person to actively participate in life of a modern democratic information society. To use the portfolio method as an effective tool for assessing students' achievements, psychological and pedagogical conditions and material bases were established, i.e. use of computers and interactive technologies, support for the experiment of introducing the portfolio method by the psychological service of the educational institution. The practical significance of the study lies in the fact that normative documents have been developed and adapted for the implementation of the portfolio method and its maintenance, recommendations are given to increase the efficiency of work on the portfolio. All this can be used by teachers at various levels of schooling in the organization of educational activities of students, assessing the quality of educational results, developing the reflective position of students, building the trajectory of an individual educational route. The results of the study will help teachers in the theoretical rethinking of the substantive and technological aspects of organizing the process of activating the learning activities of students, using the portfolio method in educational practice.
\end{abstract}

Keywords - portfolio method, educational institution, specialized training, educational process

\section{INTRODUCTION}

In modern education, the humanistic and personal orientation of the educational process is updated, which defines a qualitatively new understanding of the student as a subject of educational activity and involves the creation of conditions for the holistic manifestation, development and disclosure of the student's personality. The implementation of this approach in the educational activities of a student becomes possible only with the active position of the student.

The relevance of the study is due to the fact that in modern conditions the most important thing is not just obtaining information, but the skills and application of it, which is necessary for implementing life strategies after graduation.

Traditional student assessment tools are based on testing and reproduction. They are not focused on assessing students' abilities to perform tasks in real situations, independently find information and gain the necessary knowledge. The existing system of control and evaluation is becoming a way of developing key behavioral skills and competencies that are in demand in professional education.

Pre-profile training and specialized education at the middle and senior levels lead to the solution of issues that can be proposed to schools, the labor market and higher education. Within the framework of this training, the following conditions were created for differentiation and individualization of the learning process.

\section{THEORY, MATERIALS AND RESEARCH METHODS}

The relevance of the research topic is due to the need to resolve the contradiction between the new educational goals 
and the means of their implementation in specialized training and the lack of appropriate assessment tools. This allows us to formulate the problem: what is the model of portfolio as a tool for assessing the educational achievements of students in the context of specialized training?

In modern didactics, the portfolio method is innovative, promising and productively aimed at the quality of educational activities of students. Research interest in this method was shown by G.B. Golub [1], T.I. Gorelova [2], Yu.V. Dementieva [3], V.K. Zagvozdkina [4], M.A. Pinskaya [5, 6], T.G. Novikova [7], N.N. Smetannikova [8], and others, in the publications of which a retrospective analysis of the portfolio, the experience of using the portfolio in foreign education, the general didactic role of the portfolio in training are considered.

The purpose of the study is to test experimentally the portfolio method as a tool for assessing the educational achievements of students in the context of specialized training.

The object of this study is the profile training of students. The subject of the study is the portfolio method within the framework of specialized training.

The practical significance of the study lies in the fact that normative documents have been developed and adapted for the implementation of the portfolio method and its maintenance, recommendations are given to increase the efficiency of work on the portfolio. All this can be used by teachers at various levels of schooling in the organization of educational activities of students, assessing the quality of educational results, developing the reflective position of students, building the trajectory of an individual educational route.

The results of the study will help teachers in the theoretical rethinking of the substantive and technological aspects of organizing the process of activating the learning activities of students, using the portfolio method in educational practice.

\section{RESEARCH RESULTS AND DISCUSSION}

The idea of creating and using a portfolio in the field of education arose in the mid-80s in the USA. Further, after America and Canada, this idea is becoming increasingly popular in Europe and Japan. More recently, in Russian education, it was customary to consider a portfolio as a product of the graduate's activities "at the exit" of a particular educational level, as well as a teacher's readiness for professional activities presented in the "portfolio" ("specialist folder").

As a result of deepening the essence of understanding the term "portfolio", it was revealed that in Italian the word portfolio means "specialist folder" or "folder with documents". Modern Russian education interprets this term as "a folder of individual achievements of a student or teacher" [9]. At the same time, a "portfolio" can be considered as a "training portfolio", "work portfolio", "achievement portfolio", "professional portfolio", etc. This is due to various factors determining the feasibility of its creation, namely: the purpose of forming the portfolio itself; age category of performers of the participants who will create it; type and type of educational institution that presents its product of subject and / or vocational education to society.

Portfolio is a method of enhancing educational activities based on the cooperation of teacher-student-parent, aimed at reflecting the educational activities of students and the implementation of the individual educational trajectory of students.

So, in our understanding, "portfolio" is the document representing productive package of achievements of number of years, which is considered and accepted by many of its creators in different forms, namely as a form, method, tool and even technology, which significantly affects its structure, content component, the formation of individual thematic modules relating to a specific profile and a specific professional-specific orientation.

Currently, in domestic [10] and foreign education [11, 12 , $13,14]$, the portfolio is one of the most commonly used varieties of result-oriented technologies. However, due to the need for an objective assessment of the real achievements of students in certain subject areas and their abilities for further specialized and professional education, this technology must be considered as a global and significant phenomenon, presented as a product of the interaction of intellectual and creative obtained as a result of creative activity subject of education $[15,16]$.

The technological approach allows us to consider the "portfolio" as a pedagogical technology.

The use of portfolio in specialized classes of various directions justifies itself, because it is not only a modern effective form of assessment, but also it helps to solve important pedagogical problems:

- maintain a high educational motivation of students;

- encourage their activity and independence, expand the possibilities of learning and self-learning;

- develop skills of reflective and evaluative (selfevaluating) activities of students;

- form skills of learning - set goals, plan and organize your own learning activities

- promote the individualization (personalization) of education of students.

As a possible model, well-structured and at the same time possessing a large reserve of mobility and variability, a comprehensive portfolio model can be proposed. Comprehensive portfolio includes sections that allow you to present both the student's current work and his highest achievements, and contains a reflective block that contains a variety of materials on self-assessment, the student's planning of his own educational path and the choice of profession, his feedback and letters of recommendation.

The experiment on the introduction of the portfolio was carried out in the public educational institution Secondary school No. 16 of the city of Beloretsk on the basis of $10 \mathrm{~A}$ class with an information and technological profile. The class 
consists of 20 people: teenagers $15-16$ years old ( 5 boys and 15 girls). The experiment took place in several stages.

At the first stage of the experiment, the following documents were developed and adapted: the provision on portfolio and the portfolio model.

Portfolio Regulation is a document that normatively defines goals, objectives, and the procedure for forming a portfolio; functional responsibilities of participants in the work on the portfolio; basic portfolio structure.

Portfolio model is one or collection of portfolio types used to measure student achievement. As part of this experiment, the portfolio model was used, consisting of two sections: "section of documents" + "section of work".

In the second stage, a questionnaire was conducted, where students answered questions that helped identify the main problem areas. The survey results were processed and summarized in Table 1.

TABLE I. SUMMARY OF SURVEY RESULTS

\begin{tabular}{|c|c|c|}
\hline \multirow[t]{2}{*}{ Question } & \multicolumn{2}{|c|}{ Answer Options } \\
\hline & $A$ & $\boldsymbol{E}$ \\
\hline $\begin{array}{l}\text { Do you participate in any } \\
\text { competitions, contests, } \\
\text { conferences or projects? } \\
\text { If so, in which (list)? }\end{array}$ & 7 & $\begin{array}{l}13 \\
\text { - All-Russian Olympiad } \\
\text { for schoolchildren; } \\
\text { - Multidisciplinary } \\
\text { engineering Olympiad } \\
\text { "Star"; } \\
\text { - Competition "Whale"; } \\
\text { - International } \\
\text { Mathematical Olympiad } \\
\text { "Kangaroo" }\end{array}$ \\
\hline $\begin{array}{l}\text { Is participation in the } \\
\text { above events related to } \\
\text { your training profile? }\end{array}$ & 8 & 5 \\
\hline $\begin{array}{l}\text { For what reasons do you } \\
\text { participate in the above } \\
\text { events? }\end{array}$ & 10 & 3 \\
\hline $\begin{array}{l}\text { For what reasons do you } \\
\text { not participate in the } \\
\text { above events? }\end{array}$ & 3 & 4 \\
\hline $\begin{array}{l}\text { What educational } \\
\text { institution would you like } \\
\text { to go to (choose the } \\
\text { answer option and } \\
\text { indicate the name of the } \\
\text { institution)? }\end{array}$ & $\begin{array}{l}\text { MIEP - } 1 \\
\text { ChelSU - } 4 \\
\text { MSTU named } \\
\text { after G.I. } \\
\text { Nosova - } 5 \\
\text { HSE - } 3 \\
\text { RPUE them. } \\
\text { A.I. Herzen - } \\
1 \text { BSPU them. } \\
\text { M.A. Sharks - } \\
1\end{array}$ & $\begin{array}{l}\text { Multidisciplinary } \\
\text { College MSTU n. a. G.I. } \\
\text { Nosova - } 1 \\
\text { Beloretsk Metallurgical } \\
\text { College - } 2 \\
\text { Beloretsk construction } \\
\text { school №26 - } 2\end{array}$ \\
\hline $\begin{array}{l}\text { Do you think the } \\
\text { portfolio can help you } \\
\text { with admission? }\end{array}$ & 7 & 13 \\
\hline
\end{tabular}

Analyzing the results obtained, presented in Table 1, it is important to note that $65 \%$ of students actively participate in Olympiads and competitions, among them:

a) $62 \%$ of students accepted schoolchildren participating in the All-Russian Olympiad: in the Russian language $-31 \%$, in mathematics - $23 \%$, in computer science $38 \%$, in social studies $-15 \%$;

b) $38 \%$ of students took part in the Zvezda Multidisciplinary Engineering Olympiad;

c) $77 \%$ of students participate in the Kangaroo International Mathematical Olympiad;

d) $23 \%$ of students took part in the international competition "Whale".

Among the Olympiads and contests, in which students participated, only the Zvezda Multidisciplinary Olympiad and the All-Russian Olympiad for schoolchildren are included in the list of Olympiads that provide benefits for admission to higher educational institutions.

When considering participation in Olympiads, $77 \%$ of students answered that they are taking part in Olympiads and contests that correspond to the profile of training. At the same time, $62 \%$ take part of their own free will, and only $38 \%$ take part in the direction of teachers. Among non-participating students, $48 \%$ said that they were not interested in this area of activity, and $52 \%$ of students were not confident in their abilities.

When analyzing the choice of level of educational institutions, $75 \%$ of students chose higher educational institutions. The rest, $25 \%$ of students opted for secondary specialized educational institutions located in both Beloretsk and Magnitorsk. Most students who choose a secondary specialized educational institution do not intend to leave Beloretsk. It is also worth noting the low level of motivation in using the portfolio - only $35 \%$ of students agree that the portfolio can help with admission. In the process of filling in the portfolio, the following problems arose: participation in a small number of competitions and low motivation to use the portfolio.

Since the students chose the base university for calculating the results of the portfolio of MSTU n. a. G.I. Nosov, documents were analyzed on the procedure for accounting for individual achievements of undergraduate / specialty programs. Based on this document, student portfolios were evaluated in Table 2.

TABLE II. STUDENT PORTFOLIO EVALUATION RESULTS

\begin{tabular}{|c|c|}
\hline Number of points received & Number of students \\
\hline $0-4$ & 5 \\
\hline $5-9$ & 13 \\
\hline 10 & 2 \\
\hline
\end{tabular}

In conclusion, retest was conducted, which helped us compare the level of students' motivation and their opinion on the work done, the structure of the choice of educational institutions was re-examined.

This information was analyzed and summarized in Table 3, on the basis of which further work with students was built. 
TABLE III. SUMMARY RESULTS OF RE-SURVEY

\begin{tabular}{|c|c|c|}
\hline \multirow{2}{*}{ Question } & \multicolumn{2}{|c|}{ Answer Options } \\
\hline & $A$ & E \\
\hline $\begin{array}{l}\text { Will you participate in } \\
\text { any competitions, } \\
\text { contests, conferences } \\
\text { or projects? }\end{array}$ & 5 & 15 \\
\hline $\begin{array}{l}\text { Will you continue to } \\
\text { work on the portfolio? }\end{array}$ & 13 & 7 \\
\hline $\begin{array}{l}\text { What educational } \\
\text { institution would you } \\
\text { like to go to (choose } \\
\text { the answer option and } \\
\text { indicate the name of } \\
\text { the institution)? }\end{array}$ & $\begin{array}{l}\text { CSU - } 7 \\
\text { MSTU named after } \\
\text { G.I. Nosova - } 7 \\
\text { HSE - } 3\end{array}$ & $\begin{array}{l}\text { Multidisciplinary College } \\
\text { MSTU n. a. G.I. Nosova - } \\
1 \\
\text { Beloretsk Metallurgical } \\
\text { College }-2\end{array}$ \\
\hline $\begin{array}{l}\text { Do you think the } \\
\text { portfolio can help you } \\
\text { with admission? }\end{array}$ & 13 & 7 \\
\hline
\end{tabular}

By comparing and analyzing the results of the survey, the following conclusions were made:

1) the motivation of students to participate in various competitions and Olympiads increased by $10 \%$;

2) $65 \%$ of students will continue to work on the portfolio and believe that this will help them in applying;

3) there was a change in the choice of educational institutions for students.

Obviously, work on the portfolio has increased the number of students who are interested in entering a higher educational institution, especially at MSTU n. a. G.I. Nosova. At the same time, only $25 \%$ of students are not able to score a single additional point at the moment, $65 \%$ of students scored 5 additional points for the exam and $10 \%$ of students will be able to get the highest additional point for the exam - 10 .

\section{CONCLUSION}

To improve these results, the following recommendations were given:

1) Expanding the list of Olympiads and contests. During the survey, it was revealed that students have taken part in 4 contests and Olympiads, of which only 2 belong to the list of Olympiads for obtaining additional points during admission. To expand the lists, it was proposed to track the appearance and register students for Olympiads, including paying attention to the multidisciplinary Olympiad "Way to Success", held directly in MSTU n. a. G.I. Nosova.

2) Increasing student motivation to work on the portfolio. When analyzing the questionnaires, the problem was revealed - students were not familiar with the concept of portfolio and did not know how it affects admission. To solve this situation, extra-curricular teachers in cooperation with the school administration were invited to spend class hours on this topic with the invitation of representatives of educational institutions and student organizations.

\section{References}

[1] G.B. Golub, O.V. Churakova, "Portfolio in the system pedagogical diagnostics", School technologies, vol. 1, p. 181, 2015 .

[2] T.I. Gorelova, "Portfolio - an alternative way to evaluate learning outcomes", Management of elementary school, vol. 6 , p. 17, 2013.

[3] Yu.V. Dementieva, "The main problems of forming an electronic portfolio of students in higher education educational programs", Education and Science, vol. 2(131), pp. 145-160, 2016.

[4] V.K. Zagvozdkin, "A portfolio of - individual academic achievements is more than just - an alternative way of assessment", School technologies, vol. 3, p. 179, 2014.

[5] M.A. Pinskaya, A.A. Ponomareva, S.G. Kosaretsky, "Professional development and training of young teachers in Russia”, Educational issues, vol. 2, pp. 100-124, 2016.

[6] M.A. Pinskaya, T.E. Havenson, S.G. Kosaretsky, R.S Zvyagintsev, A.M. Mikhailova, T.A. Chirkina, "Above the barriers: exploring resilient schools", Education Issues, vol. 2, pp. 198-227, 2018.

[7] T.G. Novikova, A.S. Prutchenkov, "Portfolio as a form of assessment - individual achievements of students in the framework of - modernization of Russian education", Moscow: "Bulletin of Education" APK and ABM, 2013, 82 p.

[8] N.N. Smetannikova "Portfolio" as a technology - authentic assessment", School technologies, vol. 6, p. 160, 2016.

[9] E.G. Zinovyeva, E.G. Usmanova, "Pre-university economic training for high school students in the context of specialized education", Economics and Politics, vol. 2(12), pp. 21-25, 2018.

[10] E.G. Zinovyeva, E.G. Usmanova, "Modern problems and trends in the development of management in the field of education", Economics and Politics, vol. 1(11), pp. 26-30, 2018.

[11] N. Ivashina, M. Kuznetsova, E. Zinovieva, L. Vochel, V. Vikulina, "Features of the methods for implementing the formation of economic responsibility of students in the educational process at the technical university", EDULEARN18 Proceedings, pp. 3249-3258, July 2018 [10th International Conference on Education and New Learning Technologies, p. 11298, 2018]

[12] M. Badri, A. Nuaimi, Y. Guang, A. Rashedi, "School performance, social networking effects, and learning of school children: Evidence of reciprocal relationships in Abu Dhabi", Telematics and Informatics, vol. 34, issue 8, pp. 1433-1444, December 2017.

[13] C. Shu-Chen, C. Shing-Lin, "An innovative assessment method to establish employability map based on students' learning portfolio", Problems of education in the 21 st century, vol. 77 , issue 2, pp. 209-227, 2019.

[14] R. Amy, "Digital portfolios: a method to assess student understanding", Radiologic Technology, vol. 90, issue 2, pp. 183-186, 2018.

[15] G.I. Lazarev, S.V, Krivoshapova, V.G. Krivoshapov and A.N. Yarygin, "Creating supply chain management algorithm for university integration in the national innovation system", International Journal of Supply Chain Management, vol. 7, issue 4, pp. 440-445, 2018.

[16] G.I. Lazarev, S.V. Krivoshapova, V.G, Krivoshapov and A.N. Yarygin, "University integration management algorithm in the national innovation system", The Journal of Social Sciences Research, Special issue 5, pp. 310-315, 2018. 